\title{
Dispute Settlement Mechanisms in U.S. FTAs with Korea, Panama, Peru and Colombia: Basic Designs, Key Characteristics And Implications
}

\author{
Jaemin Lee* \\ Seoul National University, Korea
}

\begin{abstract}
The United States concluded free trade agreements (FTAs) with Korea, Peru, Panama and Colombia in late 2000s. Since the four FTAs were negotiated and concluded largely contemporaneously, key traits and characteristics of the agreements are similarly formulated. In light of this, dispute settlement mechanisms (state-to-state dispute settlement proceedings, investor-state dispute settlement proceedings, and Joint Committees) of the four FTAs also share commonalities. At the same time, new ideas and suggestions are explored in the four FTAs. While issues and disputes under the four FTAs have arguably not been ripe for the constitution of dispute settlement proceedings under the FTAs at the moment, sooner or later they are likely to end up in the dockets of the respective proceedings. The key elements of the four FTAs' dispute settlement mechanisms are also adopted in other FTAs that the United States have concluded afterwards including most recently the Trans-Pacific Partnership, since these elements are reflective of the general scheme of the United States in their FTAs. What remains to be seen is how the general scheme of dispute settlement proceedings can be applied and implemented in actual settings when the FTAs produce increasing numbers of disputes in the future. In particular, marked disparity in human and financial resources between the United States and the four FTA's parties may bring about disparate impacts and consequences among contracting parties. Continued attention needs to be paid to the development concerning implementation of the four FTAs, in particular their dispute settlement proceedings.
\end{abstract}

\section{CONTENTS}

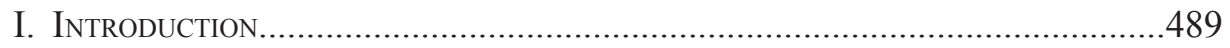

II. State-to-State Dispute Settlement Mechanism......................................490

III. Investor State Arbitration Mechanism...................................................493

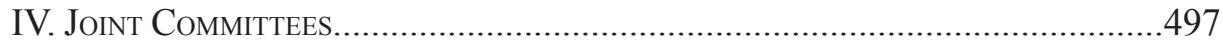

V. Assessment and Challenges................................................................499

* Professor of Law, School of Law, Seoul National University. Ph.D., LL.M., LL.B. (Seoul National Univ.); LL.M. (Georgetown Univ.); J.D. (Boston College). The author can be reached via e-mail at jaemin@snu.ac.kr. 
A. Overall Assessment of the Dispute Settlement Mechanisms of the Four U.S. Free Trade Agreements. 499

B. Peculiar Challenges for the Four Free Trade Agreements .500

1. Burden from Legal Aspects. .501

2. Burden from Logistical Aspects. .502

VI. Concluding Thoughts .503 


\section{INTRODUCTION}

The United States' free trade agreements (FTAs) with Korea, ${ }^{1}$ Peru, ${ }^{2}$ Colombia ${ }^{3}$ and Panama ${ }^{4}$ were negotiated and concluded roughly around the same time in late $2000 \mathrm{~s}$ and early 2010s. While specific terms and conditions of these agreements all vary, the frameworks used share commonalities. With respect to bilateral dispute settlement mechanisms (DSMs), the four free trade agreements also share many things in common. There are three types of different dispute settlement mechanisms that these four agreements commonly adopt. The first one is the State-to-State Dispute Settlement (SSDS) mechanism to address disputes between the state parties arising from the application of the agreements, which largely follows the basic template of the World Trade Organization (WTO) DSM in a shortened version. The second type is the Investor-State Dispute Settlement (ISDS) mechanism, a special dispute settlement mechanism to deal with investment disputes brought by investors of one contracting parties against the governments of the other contracting parties. Lastly, the four free trade agreements also include Joint Committees and sub-committees of various types to discuss issues of mutual interest, one of which is to address and resolve differences between the contracting parties in a non-judicial manner.

This essay aims to present an overview of these three types of dispute settlement mechanisms included in the four free trade agreements of the United States. The mechanisms of the four agreements arguably present the template of the U.S. FTAs when it comes to dispute settlement proceedings of free trade agreements. The same template also appears in the most recent free trade agreements that the United States have negotiated such as the Trans-Pacific Partnership (TPP), ${ }^{5}$ a megaFTA among 12 states along the Pacific Rim spearheaded by the United States. The three types of dispute settlement mechanisms are addressed respectively below.

1 The U.S.-Korea Free Trade Agreement was agreed upon on April 30, 2007 and went into effect on March 15, 2012. For the chronological history of the negotiations and conclusion, see Ministry of Foreign Affairs, Republic of Korea, FTA Status of Korea: KoreaU.S. FTA, available at http://www.mofat.go.kr/ENG/policy/fta/status/effect/us/index.jsp ?menu=m_20_80_10\&tabmenu=t_2\&submenu=s_8 (last visited Jun. 10, 2014).

2 The U.S.-Peru Trade Promotion Agreement was agreed upon on April 12, 2006 and went into effect on Feb. 1, 2009. See Department of State, Treaties in Force: A List of Treaties and Other International Agreements of the United States in Force on January 1, 2010, at 219 (2010).

3 The U.S.-Colombia Trade Promotion Agreement was agreed upon on November 22, 2006 and went into effect on May 15, 2012. See Office of the United States Trade Representative (USTR) website available at https://ustr.gov/trade-agreements/free-tradeagreements/colombia-tpa (last visited Jul. 8, 2016).

4 The U.S.-Panama Trade Promotion Agreement was agreed upon on June 28, 2007 and went into effect on October 31, 2012. See Office of the United States Trade Representative (USTR) website available at https://ustr.gov/trade-agreements/free-trade-agreements/panama-tpa (last visited Jul. 8, 2016).

5 The Trans-Pacific Partnership was signed by 12 participating states on February 4, 2016. It has yet to secure ratifications from the legislature of respective countries before it goes into effect. See Office of the United States Trade Representative (USTR) website available at https://ustr.gov/tpp (last visited Jul. 8, 2016). 


\section{State-to-State Dispute Settlement Mechanism}

At the global level, the SSDS of free trade agreements has rarely been utilized. For example, there have been only five panel reports for U.S.-Canada FTA (based on Chapter 18) and only three for North American Free Trade Agreement (NAFTA) (based on Chapter 20) for the past 20-plus years. ${ }^{6}$ The situation of SSDS in other free trade agreements is not much different. The low utilization of the FTAs' SSDS has been arguably caused by many different reasons. One of the reasons seems to be the lack or absence of secretariat support in the FTA front concerning the operation of the dispute settlement mechanism while the WTO DSM enjoys reliable logistical support from well-organized staff members. Thus, the states have found the FTAs' SSDS more difficult to invoke due to all the logistical hurdles. The situation may change as recent free trade agreements introduce new issues that do not exist in the WTO Agreements and thus any dispute involving these issues is bound to come to the docket of the FTAs' SSDS for any legal challenge. But at this point the FTAs' SSDS is still an option used only in exceptional situations.

In any event, SSDS of the free trade agreements concluded by many states largely follows the WTO's DSM as codified in the Dispute Settlement Understanding, which is arguably the most successful and robust international dispute settlement mechanism at the moment. The case number at the WTO DSM docket has now reached 507 just in 21 years since its inception in 1995. The high utilization rate vouches for the reliance and trust of states for the WTO DSM. The dispute settlement proceeding has been widely regarded as one of the signature achievements of the WTO, while there exist some areas and issues in the Dispute Settlement Understanding that require further adjustment and reform. It is fair to state, therefore, that the WTO's DSM has its own strengths and limitations despite its notable success.

There are also some key differences between the WTO's DSM and the FTA's SSDS. For instance, the FTA's DSM does not have an appellate mechanism as the WTO's DSM does. Nor does it have such a detailed text to oversee and regulate dispute settlement proceeding as the Dispute Settlement Understanding of the WTO. Much of the operation of the FTA's SSDS is left to the discretion and consensus of the two contracting parties in the future. These general characteristics of FTA's SSDS equally apply to the four agreements concluded by the United States, discussed in this essay.

As much as FTAs' SSDS follows the basic features of the WTO's DSM, the strengths and limitations of the latter similarly appear in the context of the former. At the same time, new experiments are taking place in recent free trade agreements to address some of the problems of the existing WTO's DSM in an innovative manner - such as adopting a special dispute settlement proceeding to deal with non-tariff barrier disputes. ${ }^{8}$ These new attempts, however, are not found in the four

\footnotetext{
See NAFTA Secretariat website available at http://www.nafta-sec-alena.org/en/DecisionsAndReports.aspx? $\mathrm{x}=312$ (last visited Jun. 6, 2016).

7 See World Trade Organization, Chronological List of Disputes Cases available at https:// www.wto.org/english/tratop_e/dispu_e/dispu_status_e.htm (last visited Jul. 8, 2016).

$8 \quad$ See U.S.-Korea Free Trade Ägreement, suprä note 1, annex 14-A.
} 
agreements that the United States concluded. It can be said that the U.S. FTAs adopt a rather conventional approach when it comes to dispute settlement proceedings.

With this in mind, the SSDS of the four free trade agreements have the following characteristics. First, any recommendation or ruling by a dispute settlement panel applies only in a prospective manner. ${ }^{9}$ Second, these four agreements all adopt a system of so-called "self-contained regime." 10 In other words, a dispute settlement panel established under these four free trade agreements is not permitted to turn to other international treaties or agreements or even to the WTO Agreements for governing law. Third, the four agreements do not adopt an appellate review mechanism $^{11}$ and as a result the total time required for the whole procedure is almost halved compared to that of the WTO's DSM, which usually requires 3-5 years from consultation to implementation when all steps are employed. ${ }^{12}$ Fourth, as the WTO's DSM is administered and supervised by the Dispute Settlement Body, a multilateral body represented by the heads of delegations of Member states, it is "Joint Committees" that conduct such roles for the SSDS of the four free trade agreements. ${ }^{13}$ Fifth, more than anything else, the final objective of the SSDS of the four free trade agreements is to bring the measure at issue into conformity with the agreement at issue. ${ }^{14}$ As a consequence, as in Articles 21.3 and 21.5 of the WTO's Dispute Settlement Understanding, these four agreements include procedures to determine "reasonable period of time" for implementation by a losing party and to deal with any possible compliance dispute. ${ }^{15}$ Therefore, a losing party is supposed

$9 \quad$ See U.S.-Korea Free Trade Agreement, supra note 1, art. 22.4; U.S.-Peru Trade Promotion Agreement, supra note 2, art. 21.2; U.S.-Colombia Trade Promotion Agreement, supra note 3, art. 21.2; U.S.-Panama Trade Promotion Agreement, supra note 4, art. 20.2 .

10 See U.S.-Korea Free Trade Agreement, supra note 1, art. 22.10.2; U.S.-Peru Trade Promotion Agreement, supra note 2, art. 21.10.2; U.S.-Colombia Trade Promotion Agreement, supra note 3, art. 21.10.2; U.S.-Panama Trade Promotion Agreement, supra note 4, art. 20.10.2.

11 See U.S.-Korea Free Trade Agreement, supra note 1, art. 22.12.1; U.S.-Peru Trade Promotion Agreement, supra note 2, art. 21.15.1; U.S.-Colombia Trade Promotion Agreement, supra note 3, art. 21.15.1; U.S.-Panama Trade Promotion Agreement, supra note 4, art. 20.14.1.

12 See U.S.-Korea Free Trade Agreement, supra note 1, arts. 22.8, 22.9.1, 22.9.2, 22.11.1, 22.11.4, and 22.12.1; U.S.-Peru Trade Promotion Agreement, supra note 2, arts. 21.5.1, 21.5.4, 21.6.1, 21.9.1, 21.13.3, 21.13.5, 21.14.1, and 21.15.1; U.S.-Colombia Trade Promotion Agreement, supra note 3, arts. 21.5.1, 21.5.4, 21.6.1, 21.9.1, 21.13.3, 21.13.5, 21.14.1, and 21.15.1; U.S.-Panama Trade Promotion Agreement, supra note 4, arts. 20.5.1, 20.5.4, 20.6.1, 20.9.1, 20.12.3, 20.12.4, 20.13.1, and 20.14.1.

13 See U.S.-Korea Free Trade Agreement, supra note 1, art. 22.2.2(d); U.S.-Peru Trade Promotion Agreement, supra note 2, art.20.1.2(c); U.S.-Colombia Trade Promotion Agreement, supra note 3, art. 20.1.2(c); U.S.-Panama Trade Promotion Agreement, supra note 4, art. 19.1.2(c).

14 See U.S.-Korea Free Trade Agreement, supra note 1, art. 22.12.2; U.S.-Peru Trade Promotion Agreement, supra note 2, art. 21.15.2; U.S.-Colombia Trade Promotion Agreement, supra note 3, art. 21.15.2; U.S.-Panama Trade Promotion Agreement, supra note 4, art. 20.14.2.

15 See U.S.-Korea Free Trade Agreement, supra note 1, art. 22.13.1; U.S.-Peru Trade Promotion Agreement, supra note 2, art. 21.16.1; U.S.-Colombia Trade Promotion Agreement, supra note 3, art. 21.16.1; U.S.-Panama Trade Promotion Agreement, supra note 4, arts. 20.14.3 and 20.15.1. 
to withdraw or modify the challenged measure within the "reasonable period of time", or otherwise be subject to retaliation by a prevailing party. ${ }^{16}$

One peculiar aspect of the remedy scheme of the four free trade agreements is the possibility of a losing party's offering to pay a fine to the prevailing party in lieu of bringing the measure at issue into conformity with the agreement. ${ }^{17}$ This option, in practice, does not exist in the WTO's DSM. ${ }^{18}$ Alternatively, the losing party may also decide to contribute to a fund that may be used to assist the losing party in implementing the decision of the panel to the extent such implementation requires financial resources over the years. ${ }^{19}$ Nor does the "fund" formula have its counterpart in the WTO's DSM. These reflect the four FTAs' effort to introduce more practical SSDS.

In particular, these four free trade agreements were directly affected by the bipartisan agreement on trade policy between the U.S. Congress and the U.S. administration reached in May 2007. ${ }^{20}$ The U.S. Congress demanded inclusion of new issues in U.S. FTAs that can ensure the protection of U.S. interest as a condition for the extension of the Trade Promotion Authority. ${ }^{21}$ Core issues to be newly included are those relating to labor and environment. ${ }^{22}$ As a result, dispute settlement mechanisms came to be applied to labor and environmental obligations of the agreements as well. ${ }^{23}$

16 See U.S.-Korea Free Trade Agreement, supra note 1, art. 22.13.2; U.S.-Peru Trade Promotion Agreement, supra note 2, art. 21.16.2; U.S.-Colombia Trade Promotion Agreement, supra note 3, art. 21.16.2; U.S.-Panama Trade Promotion Agreement, supra note 4, arts. 20.14.3 and 20.15.2.

17 See U.S.-Korea Free Trade Agreement, supra note 1, art. 22.13.5; U.S.-Peru Trade Promotion Agreement, supra note 2, art. 21.16.6; U.S.-Colombia Trade Promotion Agreement, supra note 3, art. 21.16.6; U.S.-Panama Trade Promotion Agreement, supra note 4, art. 20.15.6.

18 See WTO's Dispute Settlement Understanding, art. 21.1.

19 See U.S.-Korea Free Trade Agreement, supra note 1, art. 22.13.6; U.S.-Peru Trade Promotion Agreement, supra note 2, art. 21.16.7; U.S.-Colombia Trade Promotion Agreement, supra note 3, art. 21.16.7; U.S.-Panama Trade Promotion Agreement, supra note 4, art. 20.15.7.

20 See U.S. Congress House Ways \& Means Committee, Summary of the May 10 Agreement, available at http://waysandmeans.house.gov/Media/pdf/110/05\%2014\%20 07/05\%2014\%2007.pdf; Jeanne G. Grimmett, Dispute Settlement Under the U.S.-Peru Trade Promotion Agreement: An Overview, Congressional Research Service (Aug. 12, 2011), at summary.

21 See Bipartisan Congressional Trade Priorities and Accountability Act of 2015 (TPA2015) P.L. 114-26; Ian F. Fergusson \& Richard S. Beth, Trade Promotion Authority (TPA): Frequently Asked Questions, CRS RePORT (Jul. 2, 2015).

22 See Fergusson \& Beth, supra note 21, 12-13; Mary Jane Bolle \& Ian F. Fergusson, Worker Rights Provisions in Free Trade Agreements (FTAs), CRS Report IF10046 (June 18, 2015); ILO Declaration on Fundamental Principles and Rights at Work and its Followup, available at http://www.ilo.org/declaration/thedeclaration/textdeclaration/lang--en/ index.htm (last visited Jul. 8, 2016); Richard K. Lattanzio \& Ian F. Fergusson, Environmental Provisions in Free Trade Agreements (FTAs), CRS Report IF10166 (Jun. 18, 2015).

23 See Fergusson \& Beth, supra note 21, at 13; Bolle \& Fergusson, supra note 22, at 2; Lattanzio \& Fergusson, supra note 22, at 2; M. Angeles Villarreal, Proposed U.S.-Colombia Free Trade Agreement: Background and Issues, CRS Report RL34470; William H. Cooper, The Proposed U.S.-South Korea Free Trade Agreement (KORUS FTA): Provisions 
Once a dispute settlement proceeding is completed, a prevailing party may impose trade sanctions on a losing party for any failure to abide by its terms. ${ }^{24}$ Given the importance of the U.S. market for Korea, Peru, Colombia and Panama, any trade sanction by the United States could be critical for the four countries. On the other hand, trade sanction by any of the four states against the United States is likely to be less critical, albeit painful for directly related industries. As of the time of writing, no dispute has been lodged at the SSDS relating to the four free trade agreements. It will be only a matter of time, however, before cases are brought to the SSDS of the four agreements, considering the wide range of trade issues between the United States and the four trading partners. ${ }^{25}$

\section{Investor State Arbitration Mechanism}

Investment arbitration proceedings - the ISDS - are another type of dispute settlement mechanism that appears in the four free trade agreements. This is a mechanism that introduces investment arbitration for disputes initiated by an investor against the government of a host state. Unlike SSDS, this particular mechanism has attracted a great deal of attention from both the general public and opinion leaders of the five countries at issue. As a matter of fact, sensitivity associated with the ISDS proceedings of the four free trade agreements is not confined to these agreements. Rather this phenomenon is a reflection of the global trend whereby (i) the level of attention on investment arbitration has been increasing continuously and rapidly in many countries; and (ii) the legal complexities and political sensitivities associated with investment arbitration have given both foreign investors and sovereign states acute difficulties in resolving controversial international disputes. In a sense, it has become a 'hot potato' for many governments, but at the same time it has become a fixture of a free trade agreement. As such, the four agreements also incorporate ISDS proceedings. On balance, they adopt a rather standard format of ISDS proceedings while the specific elements of the proceedings slightly vary among the four free trade agreements. These differences are relatively minor and logistical in nature.

When an investment dispute cannot be resolved through consultation and negotiation, the claimant may submit the dispute to arbitration on its own behalf or on behalf of an enterprise that the claimant owns or controls, directly or indirectly. All four free trade agreements require the notice of intent submitted to the respondent at least 90 days prior to submitting any claim to arbitration. ${ }^{26} \mathrm{An}$ arbitration tribunal

and Implications, CRS Report RL34330; J. F. Hornbeck, The Proposed U.S.-Panama Free Trade Agreement, CRS REPORT RL32540.

25 In 2011, the United States and Peru had a dispute concerning the Peru's alleged failure to recognize collective bargaining rights for its workers, and the possibility of bringing an SSDS procedure was contemplated by the United States. See Jeanne G. Grimmetr, Dispute Settlement under the U.S.-Peru Trade Promotion Agreement: An Overview, Congressional Research Service (Aug. 12, 2011), at summary.

26 See U.S.-Korea Free Trade Agreement, supra note 1, art. 11.16.2; U.S.-Peru Trade Promotion Agreement, supra note 2, art. 10.16.2; U.S.-Colombia Trade Promotion Agree- 
consists of three arbitrators unless agreed otherwise by disputing parties. ${ }^{27}$ Each disputing party appoints one arbitrator, and the third, selected by their mutual agreement, becomes the presiding arbitrator. ${ }^{28}$

The four free trade agreements also adopt robust transparency provisions reflecting a recent trend of international investment arbitration spearheaded by United Nations Commission on International Trade Law (UNCITRAL) Transparency Rules ${ }^{29}$ and Transparency Convention. ${ }^{30}$ In principle, all documents submitted in the course of the proceeding should be open to public inspection subject to the exception of confidential information. ${ }^{31}$ Hearings should also be made available to the public, except any portion of the hearing dealing with the confidential information. ${ }^{32}$ A disputing party, namely a foreign investor or a respondent government, has the authority to determine which information qualifies as confidential information. ${ }^{33}$ These transparency clauses in the four agreements are reflective of the U.S. position to enhance transparency in investment arbitrations. ${ }^{34}$

In terms of awards of arbitration, the four free trade agreements prohibit an investment arbitration tribunal from providing punitive damages to a claimant. ${ }^{35}$ Nor do they allow imposition of specific action on the part of a respondent government

ment, supra note 3, art. 10.16.2; U.S.-Panama Trade Promotion Agreement, supra note 4, art. 10.16.2.

27 See U.S.-Korea Free Trade Agreement, supra note 1, art. 11.19.1; U.S.-Peru Trade Promotion Agreement, supra note 2, art. 10.19.1; U.S.-Colombia Trade Promotion Agreement, supra note 3, art. 10.19.1; U.S.-Panama Trade Promotion Agreement, supra note 4, art. 10.19.1.

28 See U.S.-Korea Free Trade Agreement, supra note 1, art. 11.19.1; U.S.-Peru Trade Promotion Agreement, supra note 2, art. 10.19.1; U.S.-Colombia Trade Promotion Agreement, supra note 3, art. 10.19.1; U.S.-Panama Trade Promotion Agreement, supra note 4, art. 10.19.1.

29 See UNCITRAL Rules on Transparency in Treaty-based Investor-State Arbitration, available at http://www.uncitral.org/uncitral/en/uncitral_texts/arbitration/2014Transparency. html (last visited Jul. 8, 2016).

30 See UN Convention on Transparency in Treaty-based Investor-State Arbitration, available at https://www.uncitral.org/pdf/english/texts/arbitration/transparency-convention/ Transparency-Convention-e.pdf (last visited Jul. 8, 2016).

31 See U.S.-Korea Free Trade Agreement, supra note 1, arts. 11.21.1 and 11.21.3; U.S.Peru Trade Promotion Agreement, supra note 2, arts. 10.21.1 and 10.21.3; U.S.-Colombia Trade Promotion Agreement, supra note 3, arts. 10.21.1 and 10.21.3; U.S.-Panama Trade Promotion Agreement, supra note 4, arts. 10.21.1 and 10.21.3.

32 See U.S.-Korea Free Trade Agreement, supra note 1, art. 11.21.2; U.S.-Peru Trade Promotion Agreement, supra note 2, art.10.21.2; U.S.-Colombia Trade Promotion Agreement, supra note 3, art. 10.21.2; U.S.-Panama Trade Promotion Agreement, supra note 4, art. 10.21.2.

33 See U.S.-Korea Free Trade Agreement, supra note 1, art. 11.21.4; U.S.-Peru Trade Promotion Agreement, supra note 2, art. 10.21.4; U.S.-Colombia Trade Promotion Agreement, supra note 3, art. 10.21.4; U.S.-Panama Trade Promotion Agreement, supra note 4, art. 10.21.4.

34 Shayerah Ilias Akhtar \& Martin A. Weiss, U.S. International Investment Agreements: Issues for Congress, CRS Report R43052 (April 29, 2013) at 11-15.

35 See U.S.-Korea Free Trade Agreement, supra note 1, art. 11.26.4; U.S.-Peru Trade Promotion Agreement, supra note 2, art. 10.26.3; U.S.-Colombia Trade Promotion Agreement, supra note 3, art. 10.26.3; U.S.-Panama Trade Promotion Agreement, supra note 4, art. 10.26.3. 
such as withdrawal of a measure. ${ }^{36}$ This limitation complies with the general trend of bilateral investment treaties (BITs) and FTAs. All four U.S. FTAs require the enforcement of the award in the domestic territory of each party. ${ }^{37}$

Another noteworthy feature of the four U.S. FTAs is the enhanced authority of the Joint Committees. When an issue arises during an investment arbitration that requires interpretation of an important provision of the investment chapter of the free trade agreement, a responding party or the government of a claimant (investor)'s nationality can refer the issue to the Joint Committee for interpretation. ${ }^{38}$ Once the Joint Committee issues an interpretation, that interpretation is binding on the investment arbitration tribunal. ${ }^{39}$ This is a unique feature that ensures the authority of the state parties to control investment arbitration tribunals when key issues are at stake. It should be noted, however, that the decision making process of the Joint Committee is based on consensus of the state parties. ${ }^{40}$ In other words, if the two state parties have divergent views on a particular provision of the free trade agreement or an issue relating to the provision, it may be difficult to secure consensus, which means that a binding interpretation may be elusive in practice. In any event, the enhanced authority of the Joint Committee represents an attempt to safeguard the authority of state parties with respect to the interpretation of key provisions of the agreement.

Concerning the conduct of investment arbitration, the Korea-U.S. FTA includes unique provisions regarding official languages and location of arbitration. Unlike the other three free trade agreements where official languages of arbitration are not specifically mentioned, the Korea-U.S. FTA has a provision that recognizes both English and Korean as official languages. ${ }^{41}$ The absence of reference to official language in the U.S. FTAs with Colombia, Peru and Panama is understandable on the basis that English is almost always the language of international investment arbitration. Due to recognition of Korean as an official language in ISDS proceedings, future arbitration could hopefully become less costly and burdensome for Korea by relying upon and submitting documents in Korean original when

36 See U.S.-Korea Free Trade Agreement, supra note 1, art. 11.26.1; U.S.-Peru Trade Promotion Agreement, supra note 2, art.10.26.1; U.S.-Colombia Trade Promotion Agreement, supra note 3, art. 10.26.1; U.S.-Panama Trade Promotion Agreement, supra note 4, art. 10.26.1.

37 See U.S.-Korea Free Trade Agreement, supra note 1, art. 11.26.8; U.S.-Peru Trade Promotion Agreement, supra note 2, art.10.26.7; U.S.-Colombia Trade Promotion Agreement, supra note 3, art. 10.26.7; U.S.-Panama Trade Promotion Agreement, supra note 4, art. 10.26.7.

38 See U.S.-Korea Free Trade Agreement, supra note 1, art. 22.2 .3 (d); U.S.-Peru Trade Promotion Agreement, supra note 2, art. 20.1.3(c); U.S.-Colombia Trade Promotion Agreement, supra note 3, art. 20.1.3(c); U.S.-Panama Trade Promotion Agreement, supra note 4, art. 19.1.3(c).

39 See U.S.-Korea Free Trade Agreement, supra note 1, art. 11.22.3; U.S.-Peru Trade Promotion Agreement, supra note 2, art.10.22.3; U.S.-Colombia Trade Promotion Agreement, supra note 3, art. 10.22.3; U.S.-Panama Trade Promotion Agreement, supra note 4, art. 10.22.3.

$40 \quad$ See U.S.-Korea Free Trade Agreement, supra note 1, art. 22.2.7; U.S.-Peru Trade Promotion Agreement, supra note 2, art. 20.1.6; U.S.-Colombia Trade Promotion Agreement, supra note 3, art. 20.1.6; U.S.-Panama Trade Promotion Agreement, supra note 4, art. 19.1.5.

${ }^{41}$ See U.S.-Korea Free Trade Agreement, supra note 1, art. 11.20.3. 
Korea becomes a respondent state. But, given that arbitrators and experts are more familiar and feel comfortable with English, it is still too early to tell whether conducting any arbitration in Korean or allowing Korea to proceed in Korean in a particular proceeding can be feasible in practice. Korea's sensitivity to ISDS proceedings is also reflected in the fact that arbitrations involving Korean government's measures are supposed to take place in Korea where there is proximity to witnesses and evidence. ${ }^{42}$ Similar provisions are not found in U.S. FTAs with other three countries.

When it comes to ISDS proceedings, the United States has placed emphasis on the possible introduction of an appellate mechanism. This is an interesting development, not paralleled in SSDS proceedings where an appellate mechanism might equally be contemplated. It can be said that the United States has been pushing for the introduction of an appellate mechanism for investment arbitration, as noted most notably in the TPP. ${ }^{43}$ Such being the case, the four free trade agreements include provisions that anticipate the introduction of appellate mechanism and the adjustment of the treaty texts once the appellate system is adopted. ${ }^{44}$ They refer to possibilities of both a multilateral appellate mechanism and bilateral appellate mechanisms. ${ }^{45}$ Likewise, the 2012 U.S. Model BIT also envisions the ultimate introduction of an appellate mechanism, although the text has no details as yet. ${ }^{46}$

The four FTAs' effort to positively consider an appellate mechanism is largely in line with the global effort to introduce the mechanism in investment arbitration. If anything, the fact that investment arbitration is conducted according to a bilateral treaty and on a one-time basis has, by its nature, caused and facilitated fragmentation of arbitral awards over the years. This phenomenon has reached the point where clear jurisprudence and reliable guidelines are sometimes lacking for governments negotiating and applying BITs and FTAs. It is against this backdrop that discussions on appeals in international investment arbitration are taking place. Introducing an appeal mechanism should help to alleviate or address some concerns raised by participants in these proceedings. But, at the same time, it should be borne in mind that an appellate mechanism, if not properly introduced or managed, may run the risk of fuelling further concerns and imposing additional burdens on the disputing parties. So the question is not necessarily whether an appellate system is necessary for the global community. Rather, the real question is what kind of an appellate mechanism is appropriate for investment arbitrations.

See U.S.-Korea Free Trade Agreement, supra note 1, art. 11.20.2.

See The Trans-Pacific Partnership, art. 9.23.11.

44 See U.S.-Korea Free Trade Agreement, supra note 1, art. 11.20.12; U.S.-Peru Trade Promotion Agreement, supra note 2, art. 10.20.10; U.S.-Colombia Trade Promotion Agreement, supra note 3, art. 10.20.10; U.S.-Panama Trade Promotion Agreement, supra note 4, art. 10.20.10.

45 See U.S.-Korea Free Trade Agreement, supra note 1, art. 11.20 .11 (b); U.S.-Peru Trade Promotion Agreement, supra note 2, art. 10.20.9 (b); U.S.-Colombia Trade Promotion Agreement, supra note 3, art. 10.20.9 (b); U.S.-Panama Trade Promotion Agreement, supra note 4, art. 10.20.9 (b).

46 See art. 28, at 10 of the 2012 U.S. Model BIT. 
As the four U.S. FTAs do not provide details of an appellate mechanism, it is difficult to predict what specific features of appellate facilities these five countries have in mind. So far, they have only established the basic principles that an appellate mechanism is worthwhile and that they will continue to discuss them when a proper opportunity arises.

\section{JoINT COMmitTeEs}

The third dispute settlement mechanism contained in the four U.S. FTAs is the Joint Committees. The Joint Committee is a consultative body composed of high ranking officials of the contracting parties. This is a body that can issue a 'binding interpretation' on the specific terms of the free trade agreement, at the request of either the contracting parties or the tribunal. As the interpretation issued by the Joint Committee binds the tribunal, this seems to be an effective way of exerting control over the investment arbitration proceeding on the part of the contracting parties. This mechanism will certainly provide peace of mind for the states.

By way of example, the Korea-U.S. FTA establishes a Joint Committee in Article 22.2 of the Agreement. Compared with the other three agreements, the U.S. FTA with Korea has detailed provisions on the role of the Joint Committee. In short, the provision sets out two categories of authority of the Joint Committee, one directive (using the term "shall") and the other permissive (using the term "may"). The provision stipulates in pertinent part that:

1. The Parties hereby establish a Joint Committee comprising officials of each Party, which shall be co-chaired by the United States Trade Representative and the Minister for Trade of Korea, or their respective designees.

2. The Joint Committee shall:

(d) seek to resolve disputes that may arise regarding the interpretation or application of this Agreement; ...

3. The Joint Committee may:

(d) issue interpretations of the provisions of this Agreement, including as provided in Articles 11.22 (Governing Law) and 11.23 (Interpretation of Annexes).

This Joint Committee is tasked with two important mandates. The first one is the authority to make a binding decision on the appropriateness of the designation by one party as protected information so as to avoid the disclosure obligation. Article 11.21 (Transparency of Arbitral Proceedings) provides in pertinent part that:

4. Any protected information that is submitted to the tribunal shall be protected from disclosure in accordance with the following procedures:

(e) At the request of a disputing Party, the Joint Committee shall consider issuing a decision in writing regarding a determination by the tribunal 
that information claimed to be protected was not properly designated. If the Joint Committee issues a decision within 60 days of such a request, it shall be binding on the tribunal, and any decision or award issued by the tribunal must be consistent with that decision. If the Joint Committee does not issue a decision within 60 days, the tribunal's determination shall remain in effect only if the non-disputing Party submits a written statement to the Joint Committee within that period that it agrees with the tribunal's determination.

At the same time, the Joint Committee is authorized to issue an interpretation of the provisions in the investment chapter that will bind reviewing investment tribunals. In the governing law provision of Article 11.22, the Agreement provides:

3. A decision of the Joint Committee declaring its interpretation of a provision of this Agreement under Article 22.2.3(d) (Joint Committee) shall be binding on a tribunal, and any decision or award issued by a tribunal must be consistent with that decision.

As the above provision shows, the Joint Committee makes important decisions that directly affect the administration of dispute settlement proceedings of free trade agreements. In particular, it is specifically stipulated that an interpretation of the Joint Committee binds the tribunal. Furthermore, the way it is stated indicates that the Joint Committee may even override any decision of the tribunal insofar as there is conflict between its own interpretation and the tribunal's decision or award. The other three agreements also include provisions that respective Joint Committees can issue binding interpretations. ${ }^{47}$ An interpretation can be requested by either a contracting party or by a reviewing tribunal. ${ }^{48}$

The Joint Committees also deal with administrative issues relating to dispute settlement proceedings. For instance, apart from the U.S.-Panama FTA, other three U.S. FTAs oblige the Joint Committee to manage the remuneration and expenses to be paid to panelists. ${ }^{49}$ They also monitor the implementation of the rulings and recommendations of the panel. They also authorize trade sanctions in the case of non-implementation. ${ }^{50}$

The four U.S. FTAs insist on consensus of the parties for every decision of the Joint Committees and other bodies established under the agreements, unless agreed

$47 \quad$ See U.S.-Peru Trade Promotion Agreement, supra note 2, art. 10.22.3; U.S.-Colombia Trade Promotion Agreement, supra note 3, art. 10.22.3; U.S.-Panama Trade Promotion Agreement, supra note 4, art. 10.22.3.

48 See U.S.-Korea Free Trade Agreement, supra note 1, arts. 11.23.1 and 22.4; U.S.-Peru Trade Promotion Agreement, supra note 2, art. 10.23.1 and 21.2; U.S.-Colombia Trade Promotion Agreement, supra note 3, arts. 10.23.1 and 21.2; U.S.-Panama Trade Promotion Agreement, supra note 4, arts. 10.23.1 and 20.2.

$49 \quad$ See U.S.-Korea Free Trade Agreement, supra note 1, art. 22.2 .2 (e); U.S.-Peru Trade Promotion Agreement, supra note 2, art. 20.1 .2 (e); U.S.-Colombia Trade Promotion Agreement, supra note 3, art. 20.1.2 (e).

$50 \quad$ See U.S.-Korea Free Trade Agreement, supra note 1, art. 22.2.3 (f); U.S.-Peru Trade Promotion Agreement, supra note 2, art.20.1.3 (f); U.S.-Colombia Trade Promotion Agreement, supra note 3, art. 20.1.3 (f); U.S.-Panama Trade Promotion Agreement, supra note 4, art. 19.1.3 (e). 
upon otherwise. ${ }^{51}$ This consensus requirement could make the operation of the Joint Committees somewhat tricky when the views of the contracting parties do not converge. If the contracting parties fail to agree upon a particular interpretation at the Joint Committee, this may delay or even derail on-going investment arbitration. Should the parties agree to present a 'compromised' interpretation which may be even more confusing than the treaty terms, the chances are that more burdens will be imposed on the investment tribunal. It will be interesting to watch how the four free trade agreements administer their respective Joint Committees.

At the same time, this new attempt of four free trade agreements also raises new questions, both in terms of policy and legal aspects. First, with respect to the policy aspect, the new system may end up restraining the otherwise legitimate authority of the adjudicative body. A concern is that the Joint Committee may issue a compromised interpretation which is not supported by the "ordinary meaning" principle as clarified by the 1969 Vienna Convention on the Law of Treaties (Vienna Convention). An argument can then be made about whether this will further 'politicize' the investment arbitration proceedings. As to the legal aspect, the scope and meaning of "binding interpretation" are not entirely clear. For instance, controversies may arise as to whether the Joint Committee can simply issue interpretation of the words contained in the text based on ordinary meaning or whether it can also purport to pronounce interpretation of the terms that already carry certain legal implications in and of themselves in the investment agreement context - such as the terms "investor" or "investment" - which may ultimately dispose of the legal claims at issue. Needless to say, any interpretation of treaty terms is subject to the general rules of treaty interpretation as pronounced in the Vienna Convention. In that respect, the same rules of interpretation apply to both categories of interpretation. Nonetheless, interpretation in the latter category is arguably directly related to resolution of key legal issues of investment disputes. Disposition of these legal issues should be left to adjudicators, namely tribunal, and arguably would not be amenable to ex post facto decisions of the contracting parties. The first category of interpretation, on the other hand, can be regarded as clarification or elaboration by contracting parties, which may indeed help arbitrators and tribunal in a dispute. This is another task left to the further elaboration of Joint Committee's operation by the five contracting parties in the future.

\section{Assessment And Challenges}

\section{A. Overall Assessment of the Dispute Settlement Mechanisms of the Four U.S. FTAS}

Review of the dispute settlement mechanism of the U.S. FTAs with Korea, Peru, Colombia and Panama highlights the importance of the mechanism in the

$51 \quad$ See U.S.-Korea Free Trade Agreement, supra note 1, art. 22.2.7; U.S.-Peru Trade Promotion Agreement, supra note 2, art. 20.1.6; U.S.-Colombia Trade Promotion Agreement, supra note 3, art. 20.1.6; U.S.-Panama Trade Promotion Agreement, supra note 4, art. 19.1.5. 
architecture and scheme of the free trade agreements. It is supposed to operate as a main pillar for the implementation of the respective agreements. The SSDS proceedings of the four agreements have adopted the basic template of the WTO's DSM, except the appellate proceedings. The timeframe for the entire proceeding has been reduced almost by half compared to that of the WTO's DSM, which may incentivize the utilization of the proceeding in the long run. But at least in the initial stage, it is not likely that these FTAs' SSDS proceeding is somehow invoked in the near future. In any event, except for Korea, the other three countries have not had a dispute with the United States that has proceeded to the WTO's DSM. It can be argued, therefore, that the prospect of invocation of the FTAs' SSDS by these three countries is relatively low unless an acute FTA-specific dispute arises between them and the United States. Korea, however, has already had as many as 10 disputes with the United States and dissatisfaction with Korea's implementation of U.S.-Korea FTA has been increasing incrementally, so that there is potentially a greater likelihood that the U.S.-Korea FTA's SSDS proceeding will be invoked in the near future.

The ISDS proceedings of the four free trade agreements largely follow the general scheme of the proceedings adopted in the BITs and investment chapters of other FTAs. It can be said that the four agreements have included more detailed provisions for investment arbitration reflecting concerns of the parties who will stand to face arbitration as respondents. These additional provisions are supposed to safeguard the interest of the host states' governments by clarifying or imposing requirements to be satisfied by foreign investors to invoke the ISDS proceedings. Notwithstanding these additions and clarifications, the basic framework of investment arbitration either under International Centre for Settlement of Investment Disputes or UNCITRAL rules remains intact. This would mean that the concerns over the ISDS proceedings stemming from fears of possible erosion of a state's regulatory authority still apply to the ISDS proceedings of the four agreements.

Joint Committees of the four free trade agreements are also supposed to play an important role in the administration of the agreements. These committees are non-binding consultative bodies, but offer a forum to discuss and resolve disputes arising from the free trade agreements. At the same time, the committees are tasked with organizing, administering and monitoring dispute settlement proceedings initiated under the FTAs' SSDS mechanism. Furthermore, Joint Committees can issue interpretation of the texts of the agreements which are binding on panels of SSDS and arbitration tribunals of ISDS. In short, Joint Committees can play an important role either in settling disputes directly or in facilitating the settlement of disputes under the free trade agreements. There are also sub-committees in charge of respective sectors of trade issues of the agreements such as goods, services, and intellectual property rights.

So, the four free trade agreements adopt dispute settlement mechanisms that can deal with various disputes arising from the implementation of the trade agreements. As the implementation of these agreements is still in an early stage, it seems to be too early to evaluate the performance of the mechanisms in general or respective proceedings in particular. But at least it can be said that a framework has been put in place to deal with a variety of disputes between the state parties. 


\section{B. Peculiar Challenges for the Four Free Trade Agreements}

There are challenges facing the state parties of the four free trade agreements when it comes to the dispute settlement mechanism. Of course, there are challenges pertaining to the fundamental nature of the dispute settlement mechanism, which appear in all mechanisms, such as the issue of forum shopping, cross-over between trade disputes and investment disputes, and fragmentation of dispute settlement proceedings. Attempts are being made to address these fundamental challenges in various fora and agreements. Setting aside these fundamental issues inherent to the mechanisms of recent free trade agreements, there are peculiar issues that apply to the four agreements specifically.

Most notably, there is marked discrepancy between the United States on the one hand and the other four trading partners on the other hand. Thus, when it comes to the utilization of or participation in the dispute settlement mechanisms of the free trade agreements, burdens to fall on the state parties may arguably be disproportionate in a significant manner. Neutral texts notwithstanding, the huge discrepancy in resources would place the United States in a better position to participate in the dispute settlement mechanisms either as a complainant or a respondent compared to the other four countries. Among the four countries, perhaps Korea can be distinguished from Peru, Panama or Colombia. But the gap in resources and manpower between Korea and the United States is still conspicuous.

\section{Burden from Legal Aspects}

The four free trade agreements purport to introduce new provisions that do not necessarily appear in the WTO Agreements. Tariff reduction or elimination is often cited as the key element of a free trade agreement, but from the systemic perspective this is a relatively easy and straightforward process. It is mainly about calculation of the amount to be reduced or eliminated and how to find a compromising point between the two countries. It is the new issues and new norms introduced in a free trade agreement that have a far reaching impact on state parties. Laws and regulations should be amended or introduced, and practices and policies changed or adjusted. Such amendments or changes take time, even if there is willingness on the part of the state parties of a trade agreement.

In this respect, attention needs to be drawn to the fact that the four free trade agreements attempt to introduce new rules and norms in various sectors. By way of example, the four agreements have independent chapters on environment, labor and investment which are not dealt within the WTO Agreements. ${ }^{52}$ To the extent these new rules require changes in the existing laws and regulatory systems of the contracting parties, a new set of obligations are imposed on these states. As these new rules do not have precedents in the WTO regime, reliable guidelines are not available at least in the early stage of the implementation. As with any other

$52 \quad$ See U.S.-Korea Free Trade Agreement, supra note 1, chs. 20 (Environment), 19 (Labor), and 11 (Investment); U.S.-Peru Trade Promotion Agreement, supra note 2, chs. 18 (Environment), 17 (Labor), and 10 (Investment); U.S.-Colombia Trade Promotion Agreement, supra note 3, chs. 18 (Environment), 17 (Labor), and 10 (Investment); U.S.Panama Trade Promotion Agreement, supra note 4, chs. 17 (Environment), 16 (Labor), and 10 (Investment). 
new norms in a treaty, it is not entirely clear what the new provisions mean and how they should be interpreted. Clarification and elaboration usually come as a result of discussions, consultations and sometimes disputes between the parties. Sometimes, even if a party to a free trade agreement is willing to implement a provision to the letter as soon as possible with swift adoption of implementing legislation, it takes time to change deeply rooted, existing practices. Less than optimal implementation, for whatever reason, tends to frustrate the other party to an agreement. The frustration may lead to initiation of official dispute settlement proceedings under the dispute settlement mechanisms of free trade agreements. In short, the advent of new rules and new norms make it more likely that disputes between the parties arise and mechanisms are ultimately invoked.

Needless to say, the introduction of new rules imposes the same obligations on both parties to a free trade agreement. The texts are neutral and the parties are subject to the same texts. So, both parties assume new burdens as a result of the conclusion of a free trade agreement. But the actual burden on parties to a free trade agreement arising from the new rules could vary. This is particularly the case when the two parties show a stark gap in terms of economic development and the situations in the market. New issues usually reflect ideas and suggestions formulated in developed states. All things being equal, developed states would find provisions introducing the new rules more familiar and comfortable than their developingstate counterparts. National legislations and schemes to address the new issues have already been adopted or can be adopted relatively easily.

That is not necessarily the case for developing states. As such, when it comes to the four U.S. FTAs, the introduction of new rules and norms in these free trade agreements poses a disproportionate challenge to the four contracting parties of the agreements. In particular, Peru, Colombia and Panama are developing states that would have difficulties in dealing with new requirements and technicalities arising from the new rules and norms. This de facto disparity in FTAs' implementation needs to be taken into consideration in reflecting dispute settlement mechanism of the four agreements.

\section{Burden from Logistical Aspects}

As each free trade agreement has its own dispute settlement mechanism, the number of mechanisms that one state should deal with increases commensurate with the number of agreements. As participation in the dispute settlement mechanism entails significant human and financial resources, the overall logistical burden for a government entangled in the web of free trade agreements can be sometimes substantial. Such logistical burden can be disproportionately large for developing states that have limited human and financial resources. United States' four FTA's partners would face similar difficulties albeit the specific burden may vary.

Assuming the current situation of dormancy is maintained in the FTA's DSM, the logistical burden for developing states would not be materialized. Once the situation changes, however, developing states are likely to find themselves in a difficult situation of dealing with multiple dispute settlement proceedings in a limited timeframe. Again, both parties to a free trade agreement would face an increased burden, but it is developing states that would face a higher logistical burden. The four FTA's partners of the United States would experience a similar phenomenon. 
The four free trade agreements adopt a conventional definition of a "measure" to be challenged at the dispute settlement mechanisms. The definition of a "measure" is so broad that it may capture a wide range of governmental action and inaction of a state. ${ }^{53}$ As long as there is a "measure" falling under the free trade agreement at issue, a dispute settlement proceeding can be initiated. ${ }^{54}$ Consequently, it is not surprising and in fact merely a matter of time that a governmental measure is brought to an FTA's DSM when circumstances so require. Once the initial stage is over and the four U.S. FTAs are brought to a full implementation mode, dispute settlement mechanisms are expected to be mobilized in full swing. WTO's DSM will be utilized continuously, but in addition, FTAs' DSMs will have to be invoked as well so as to address new issues that do not appear in the WTO Agreements in which case only FTAs' DSMs can offer viable fora.

In other words, in the near future, four FTA partners of the United States will have to deal with multiple dispute settlement mechanisms - both WTO's DSM and various mechanisms in their respective free trade agreements with the United States. This would mean that these partners would have to deal with a thinly stretched workforce with limited resources. As much as dispute settlement mechanisms take an important position in the free trade agreements, these four countries' utilization of free trade agreements might be limited accordingly.

\section{Concluding Thoughts}

The United States concluded free trade agreements with Korea, Peru, Panama and Colombia in late 2000s and brought these agreements into force in late 2000 s or early 2010s. Diverse reasons spanning over economic rationale and geopolitical considerations have prompted the U.S. government to push ahead with these preferential trade agreements with these four countries. Since the four agreements were negotiated and concluded largely contemporaneously, key traits and characteristics of the agreements are similarly formulated. In light of this, the dispute settlement mechanisms of the four agreements also share commonalities. Needless to say, there are state-specific variations in the four agreements, but they are generally minor adjustments rather than fundamental differences.

In summary, SSDS proceedings, ISDS proceedings and Joint Committees are the three main schemes for addressing disputes arising from the implementation of

53 The term "measure" is defined by the WTO Appellate Body in US - Corrosion-Resistant Steel Sunset Review where it stated that: "In principle, any act or omission attributable to a WTO Member can be a measure of that Member for purposes of dispute settlement proceedings" (emphasis added). Measures that can be subject to WTO dispute settlement can include, not only acts applying a law in a specific situation, but also "acts setting forth rules or norms that are intended to have general and prospective application ... instruments of a Member containing rules or norms could constitute a 'measure', irrespective of how or whether those rules or norms are applied in a particular instance." This definition is also accepted by the four free trade agreements discussed in this chapter.

54 See art. 1.1 of the WTO's Dispute Settlement Understanding. For a free trade agreement, see, e.g., art. 22.4 of the U.S.-Korea Free Trade Agreement, supra note 1. 
the four free trade agreements. SSDS proceedings are supposed to deal with alleged violation of provisions of free trade agreements, following the general contours of the WTO's DSM, although in a shortened timeframe and except for an appellate mechanism. ISDS proceedings are going to deal with investment arbitration that is receiving increasing attention globally these days due to the sensitivity relating to the regulatory authority of a government. Some new ideas are included in the four free trade agreements to address the concern of the respondent governments, but they are generally minor and logistical. Joint Committees are non-binding consultative bodies that also play an important role in settling bilateral disputes. As detailed provisions of dispute settlement proceedings are introduced in the four free trade agreements, they are ready to be utilized by state parties to the agreements. Issues under the free trade agreements have arguably not been ripe for the constitution of dispute settlement mechanisms under the agreements at the moment, but sooner or later they are likely to end up in the dockets of the mechanisms.

The key elements of the four FTAs' DSM are also adopted in other free trade agreements that the United States have concluded afterwards including most recently the TPP, since these elements are reflective of the general scheme of the United States in their free trade agreements. The TPP, a 12-state mega-FTA signed in February 2016, adopts dispute settlement mechanisms that are similar, in all material respects, to the four agreements with Korea, Peru, Colombia and Panama.

What remains to be seen is how the general scheme of dispute settlement mechanisms can be applied and implemented in actual settings when the free trade agreements produce increasing disputes. In particular, the marked disparity in human and financial resources between the United States and the four FTA's parties may impose disproportionate burdens on the latter in utilizing and participating in the new mechanisms of the agreements. WTO's DSM may have seen a similar phenomenon, but the advent of multiple mechanisms in addition to the WTO's DSM may arguable exacerbate the inherent limitations of developing states even further. Continued attention needs to be paid to the development concerning implementation of the four free trade agreements. 